\title{
THE PERSPECTIVES AND ROLES OF RENEWABLE ENERGY SOURCES IN THE ECONOMIC DEVELOPMENT OF PERIPHERAL AREAS OF HUNGARY
}

\section{Adrienn NAGY, Kitti KOLLÁR, László PÉLI}

\author{
Szent István University, Faculty of Economics and Social Sciences, Institute of Regional Economics and Rural Development, Hungary
}

\begin{abstract}
The everyday use of renewable energy sources is necessary and indispensable in today's modern world, partly because of the difficult handling of environmental problems caused by the increasing use of fossil energy sources, and partly because of the still increasing energy demand. Concerning alternative energy sources, Hungary has great potential in geothermal energy, which can mean a breakout especially for the peripheral, disadvantaged micro-regions while developing their future strategies. This was the motivation of our research. In our study, we intended to highlight the economic development perspectives of the Hungarian micro-regions lagging behind regarding the renewable energy potential.
\end{abstract}

Keywords: renewable energy sources, the economic development

\section{Introduction}

The abovementioned national resource is very significant from both potential and perspective point of view. Hungary has favorable geothermal conditions: while in other countries the temperature increases by 30-33 degrees Celsius per kilometer downward, this value is 42-56 degrees Celsius in our country. At the depth of 2,000 meters, rock (and water in the porous rock) temperature usually exceeds 100 degrees Celsius. The estimated volume of Hungary's thermal waters is 2,500 cubic kilometers, and the heat energy stored is 604,000 PJ (peta-Joule). Presently, there are more than 100 licensed, thermalwater producing wells registered at the Mining Bureau of Hungary (Nagy and Káposzta, 2003). Most wide-spread uses are the heating of agriculture facilities (greenhouses), public and residential buildings, and the water supply of baths and swimming pools. The rather high investment requirement and the high material content in solutions considerably increasing operation costs limit a wide range of applications (http://waterfire.fas.is).

With its widely spread resources, geothermal energy is a resource which can noteworthily contribute to the future energy provision in Visegrad Countries. Whereas the direct use of geothermal heat can already compete on the market due to the high oil and gas prices, geothermal electricity generation faces huge financial challenges in most European regions.

Besides the use of high enthalpy fields - which are limited to a few places and are in most cases already used - an extended geothermal electricity generation in the future depends especially on the larger potential of low enthalpy or hydro-geothermal resources. These resources have been scarcely exploited so far. Apart from technical challenges, economic barriers hinder the wider use of hydro-geothermal energy within Europe. The most important usage in European Countries:

$\square$ Iceland - heat everywhere, district heating, electricity (Al smelting).

$\square$ Switzerland - Highly developed ground source pump installation and deep borehole in Upper Rhine Graben.

$\square$ Sweden - Developed ground source heat pump installation, Stockholm marine.

$\square$ Germany - Aachen borehole project, Upper Rhine Graben, Unterhaching, Bad Urach, Neustad-Glebe, Bruchsal, Bayern.

$\square$ Hungary - Budapest spas and district heating, great sites.

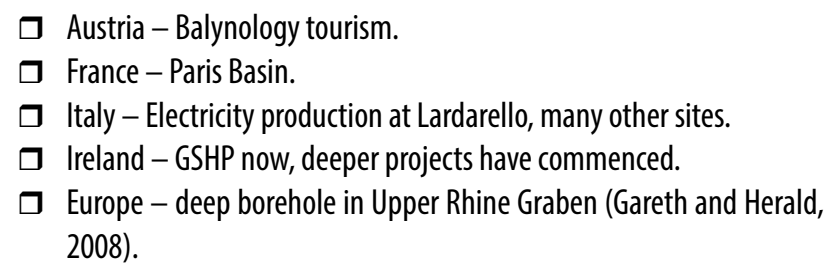

\section{The perspectives of geothermal energy in Hungary}

Hungary is located in the middle of the Pannonian Basin in Central Europe. The Pannonian basin is a Neogene extensional setting formed between the Carpathian and Dinaride thrust belts within the mega-suture zone of the African and European plates with a relatively thin crust 25 to $35 \mathrm{~km}$ thick. The basement of the basin consists of higher thermal conductivity PrecambrianPaleozoic-Mesozoic rocks. The basin is filled with lower thermal conductivity Cenozoic sediments, the thickest sequences formed during the upper Miocene, Pannonian age. The Pannonian sediments are multilayered and composed of sand, shale and silt beds. While the lower Pannonian sediments (e.g. clay, silt, marl) are impermeable, the upper Pannonian and Quaternary formations contain vast porous, permeable sand and sandstone beds formed by the upper Pannonian aquifer (Bobok et al., 1998).

According to thermo-tectonic models, the initial crustal thinning or rifting of the Pannonian basin occurred in the Middle Miocene and the subsequent thermal subsidence or post-rift phase extended up to the present. During the history of the basin, significant tectonic events happened mostly in the Miocene. Along the main tectonic lines (like Mid-Hungarian line, Balaton line, Vatta-Maklár line), significant strike slip movements happened. These movements broke the basement rocks causing high secondary porosity.

Along some tectonic lines high pressure geothermal conditions experienced (Árpási et al., 2000; Tóth and Almási, 2001). As a result of the Earth's thin crust, Hungary's geothermal gradient is higher than the world average. At the depth of 2,000 meters, rock (and water in the porous rock) temperature often exceeds $100{ }^{\circ} \mathrm{C}$ (Hungarian Geological Survey, 2002), which can be seen on the Figure 1 .

Concerning the geothermal energy utilization, there are vast areas of unexploited geothermal options within Hungary. Considerable amount of 


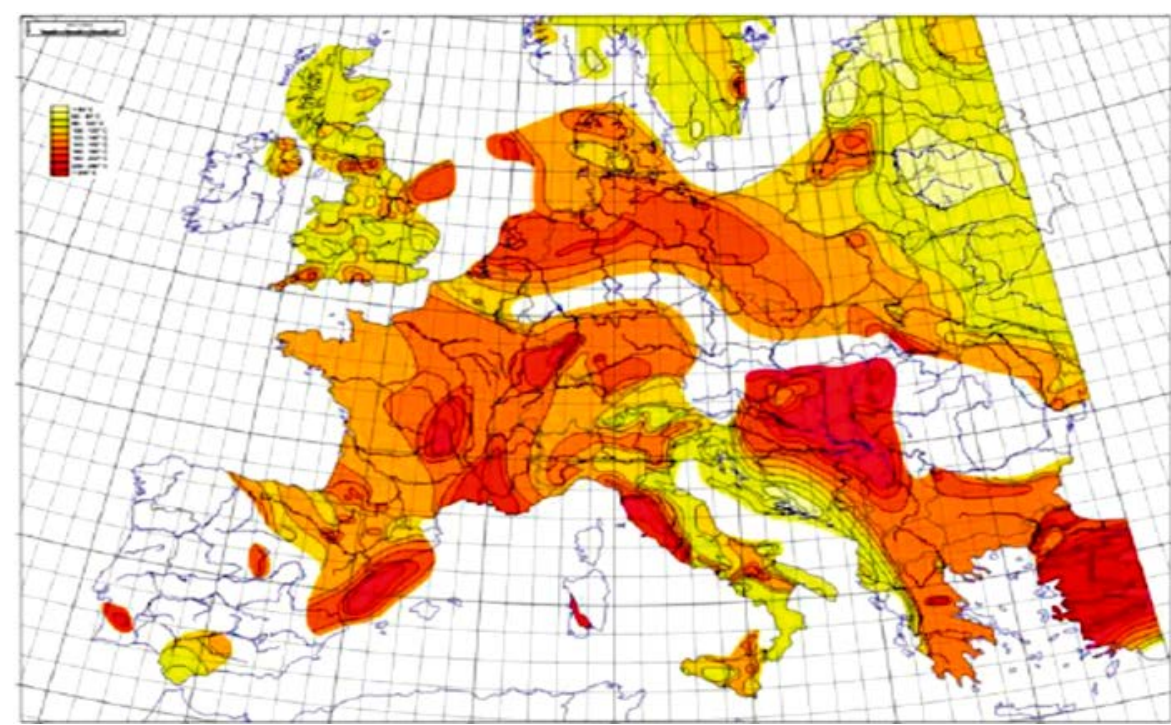

Figure 1 Temperatures recorded in Europe at the depth of 5000 meters

Source: The possible maximum use of heat content of geothermal energy based on national and international examples (Kujbus, 2012) information and data on the various fields are available and many wells have already been drilled, either for oil or for thermal water. The oil wells are usually deeper than $3 \mathrm{kms}$, but the thermal wells are most commonly less than $1 \mathrm{~km}$ deep. The objective is to find geothermal water for power generation at depth in-between $1 \mathrm{~km}$ and perhaps down to 4 or $5 \mathrm{kms}$ (Tulinius et al., 2008).

The geothermal conditions of Hungary are as follows (Ádám et al., 2009): $\square$ Geothermal energy is available in high quantity; therefore it reduces the dependence on import energy.

$\square$ Geothermal heat can be 'sustainably' used.

$\square$ Geothermal energy is available all the time, thus we can consider it as a basic energy source.

$\square$ The use of geothermal energy does not have harmful emissions. The $\mathrm{CO} 2$ surplus can be traded on the bourse.

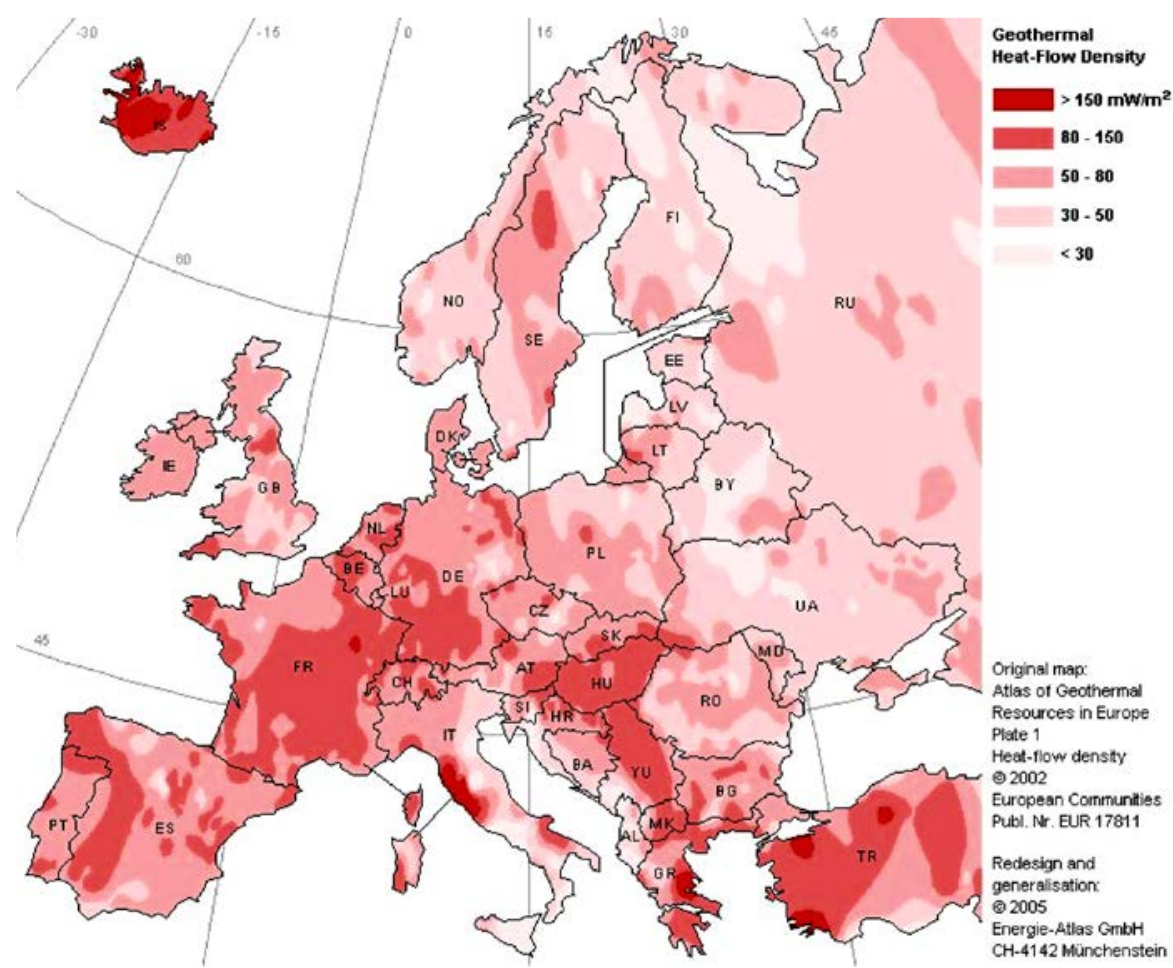

Figure 2 The map of geothermal energy in Europe: Hungary has a favourable place Source: http://www.piacesprofit.hu/klimablog/energia $\square$ The life expectancy of geothermal projects based on the state of the systems operating from more than 50 years - is minimum 50-70 years; therefore despite of the higher investment costs, their economical features cannot be questioned.

Based on the abovementioned, it can be stated that the outstanding geothermal conditions of Hungary are well-known. Our thermal water is our determining national treasury. Its utilization of decades increased the fame and economic operation of most of our largest health resorts and thermal baths, horticultural plants, as well as the ability of rural areas to keep the rural population (Nagy and Káposzta, 2006). However, we must not forget that the dynamic thermal reserves available - with rational management - are able to provide much more than the current amount (3-4 PJ/year) sustainably even in long terms. We believe that it is important to mention that the thermal potential predicts 100-110 PJ/year utilization, which is $20 \%$ of Hungary's heating demand (Ádám et al., 2009).

Moreover, we need to mention that the rate of geothermal energy in the energy balance of Hungary is $0.29 \%$. It accounts for only $6.6 \%$ of the renewable energies in addition to approx. $86 \%$ share of biomass and wood together (Mádlné et al., 2008).

There is thermal water under $80 \%$ of our land. It is of high temperature and has high content of minerals; we are among the top five countries (Japan, Iceland, Italy, France, and Hungary). If we go into the details, we can see that in Japan and Iceland, the thermal water has high temperature but low mineral content, while that of Italy and France has high mineral content but the temperature does not reach that of the water in the Carpathian-basin. Therefore, our water is unique worldwide, with having high temperature and also high content of minerals (Nagy and Káposzta, 2004).

\section{Territorial scope of the research}

In our research we focused on the 47 leastdeveloped micro-regions, with special focus on the 33 ones requiring complex development programs. According to the Act 2007./CVII., there are 174 statistical micro-regions in Hungary, thus we collected the basic data for the least-developed micro-regions according to the categories of the Parliamentary provision No. 2007/67 and Governmental regulation No. 2007/311. The 33 LDCDP micro-regions are located in 4 regions and in 12 counties as it can be seen on the map below. 


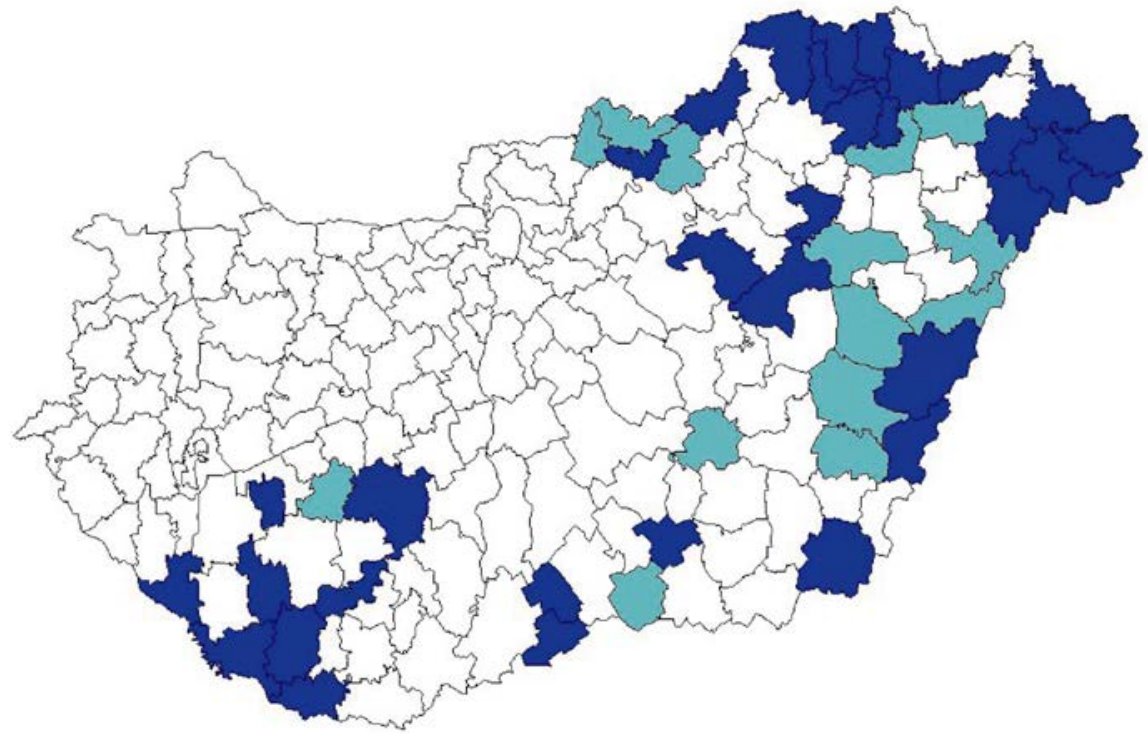

Figure 3 The location of the Hungarian LD and LDCDP micro-regions Source: own editing based on CSO data (2011), 2011

LD - least-developed micro-region; LDCDP - least-developed micro-region requiring complex development program LD (14), $\square \operatorname{LDCDP}(33)$
In the rest of the study we wish to highlight the fact that the least-developed micro-regions have very good geothermal potential, which can be a solution for the problem of poor human resources and the lack of jobs (that are detailed in the followings).

In the Figure above it can be seen that the least-developed micro-regions have outstanding thermal water reserves, since the thermal water of $60^{\circ} \mathrm{C}$ or even above is concentrated in these areas. Thus it can be a breakout for the micro-regions located in those areas. The use of thermal water in Hungary is various. Flats and public institutions use thermal water for heating,

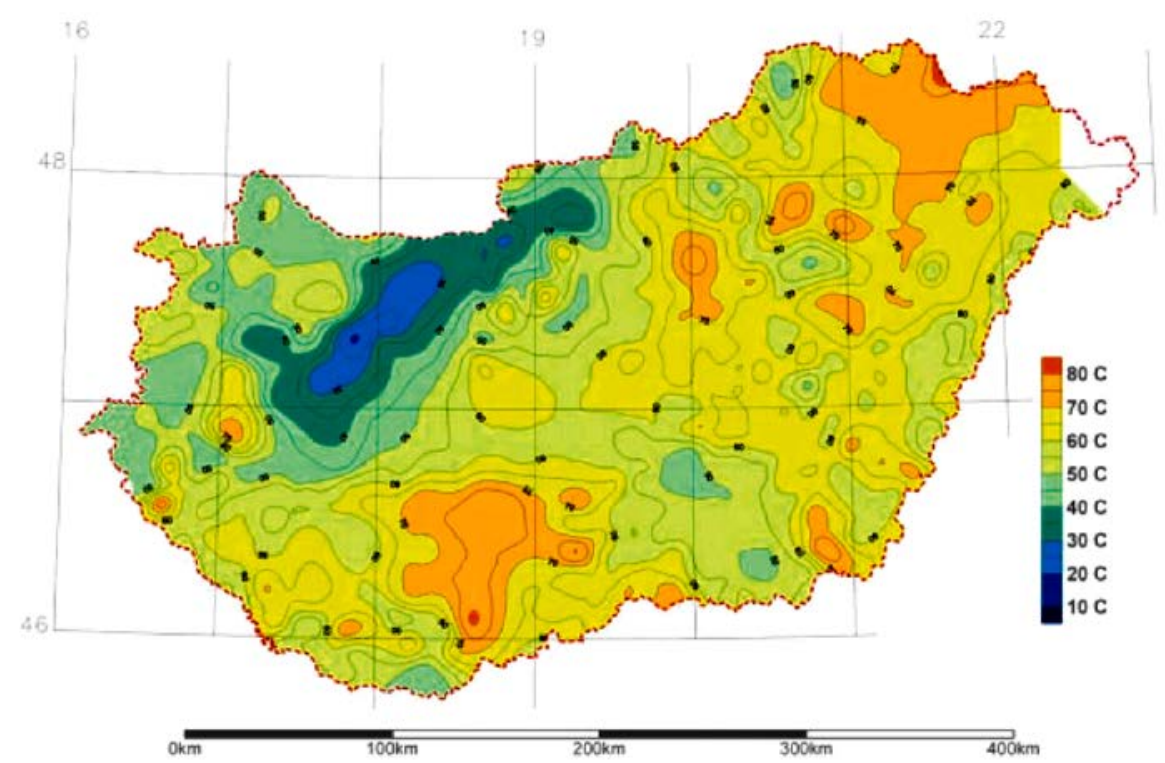

Figure 4 The distribution of temperature at the depth of 1000 meters Source: Mádlné, 2006 while it is used for heating industrial factories or providing technological hot water (Kóbor, 2008). At the moment, there is no significant electricity production based on geothermal energy, although the potentials are given. There are several wills providing water with surface temperature of over $85^{\circ} \mathrm{C}$, potentially suitable for operating electricity generating systems with performance of 0.1 0.5 MWh (Patay, 2007). In addition to other forms of use, it can also be utilized in agriculture in open fields or in green houses. In open lands, thermal water can be used for irrigation and the heating of soil. Their joint effect can prevent the damage caused by the rapid cooling down of soil, therefore the production/growing period can be expanded (Mádlné, 2006).

In our opinion, where there is thermal water available and there is agricultural production, the heating of foil greenhouses is perfectly carried out and well operated. In the least-developed microregions the unemployment rate is high, there are not enough jobs and there is poor human resource, thus the unexploited potential of geothermal energy can be a possible development path for agriculture. Therefore jobs could be created in such micro-regions which would prevent the large-scale migration of young people from those micro-regions (Káposzta, Nagy and Kollár, 2010).

The greenhouses are heated with the thermal water which has already cooled down in other stages of the heating process. The other major field of thermal water utilization in agriculture is the drying of fodder. In such cases, the thermal water of $40-60^{\circ} \mathrm{C}$ in appropriate quantity is used to dry the fodder partly or totally. During the drying process of green fodder, hot air thermal water is used. In such cases, the thermal water is suitable only for pre-drying, which may result in significant saving of fuel (Patay, 2007).

\section{Conclusion and recommendations}

Based on our research findings, it is clear that the selected micro-regions lag well behind the national average regarding both economic and social indicators. In our opinion, the following factors have contributed much to their break off:

1. the low quality of human resource,

2. high rate of migration,

3. bad infrastructure and

4. problems of the social groups.

As a result of our researches, we make some recommendations (strategic guidelines) how to improve the competitiveness of such micro-regions in long-terms, which are, at the moment, stagnating or breaking off. We suggest the application of demand-oriented regional strategy on the basis of the special internal conditions in the least-developed micro-regions as well. Thus, the comparative advantages of the restricted factors of the rural land-use (natural endowments, landscape protection areas etc.), could be utilized. In order to optimize the rural land-use, we suggest the preference of alternative energy sources, sustainable technologies and food industry, which could result in the increase of rural added value in the least-developed microregions.

Regarding the economic aspects, it is important to know in what scope the investment 
and production costs of geothermal energy can compete with the conventional energy sources. It is also important to answer the question why the geothermal energy is recommended to be used in a given area instead of other renewables. Concerning fossil fuels, the planning, establishing and operational costs need to be set from economic point of view. The price of the 'product' and the operational costs determine how much the existing geothermal plants are economical. Before establishing a new geothermal plant, however, the collection of local conditions and information is really important.

Based on all these factors, we can conclude that a more careful utilization and exploitation of geothermal energy (especially thermal water) in the least-developed micro-regions i.e.. the focus of our research is highly recommended, both in households and in the agricultural production. We believe that the major breakout points in such areas are self-supply regarding agricultural products and the strengthening of local markets which can be accelerated and supported by the thermal water reserves of high temperature under the ground surface.

\section{References}

ÁDÁM, B. - KUJBUS, A. - KURUNCZI, M. - SZANYI, J. - UNK, J.-né 2009. Javaslat a geotermikus energia hazai hasznositásának növelésére. Kézirat. Kistelek, 2009. február 18.

ÁRPÁSI, M. - LORBERER, Á. - PAP, S. 2000. High Pressure and Temperature (Geopressured) Geothermal Reservoirs in Hungary. World Geothermal Congress 2000, KyushuTohoku, Japan, 28 May-10 June.

BOBOK, E. - JOBBIK, A. - TAKÁCS, G. 1998.: Present stauts of geothermal energy utilization in Hungary. In: Bulletins of Geothermal Resources Council, vol. 22, 1998, pp. 211-214.

GARETH, LL. J. - HERALD, L. 2008. Geothermal Energy in Europe, Flagstaff, IPGC ENGINEproject (2005): Workpackage 5 - Economic analysis of geothermal energy provision in Europe

KÁPOSZTA, J.- NAGY, H.- KOLLÁR, K. 2010. Borsod-Abaúj- Zemplén és SzabolcsSzatmár-Bereg megye leghátrányosabb helyzetü kistérségeinek településszerkezeti, foglalkoztatási jellemzői az EU-csatlakozás óta eltelt időszakban. In: Területi Statisztika, vol. 50, 2010, no. 6, p. 641-658.
KÓBOR, B. 2008. Az alternatív energiahasználat fejlesztési lehetőségei a dél- alföldi régióban. Csongrád Megyei Önkormányzat.

KUJBUS, A. 2012. A geotermikus hőtartalom maximális hasznositásának lehetőségei hazai és nemzetközi példák alapján, Budapest, 2012, p. 3.

MÁDLNÉ SZŐNYI, J. - RYBACH, L. - LENKEY, L. - HÁMOR, T. - ZSEMLE, F. 2008. Fejlődési lehetőségek a geotermikus energia hasznositásában, különös tekintettel a hazai adottságokra. Budapest: MTA, 2008.

MÁDLNÉ SZŐNYI, J. 2006. A geotermikus energia: készletek, kutatás, hasznositás. Grafon Kiadó, Nagykovácsi.

NAGY, H.-KÁPOSZTA, J. 2003. The role of multifunctional environmental policy int he agricultural development. In: Annals of the Polish Association of Agricultural and Agribusiness Economists, vol. 5, 2003, no. 6, p. 28-34.

NAGY, H. - KÁPOSZTA, J. 2006. Economic development strategies and development zones int he European Union. In: Bulletin of the Szent István University-Gödöllő, 2006, no. 1, p. 163-172.

PATAY, I. 2007. Mindentudás a megújuló energiaforrásokról a Dél- Alföldi régióban. Kolorprint Kft., Békéscsaba.

TÓTH, J. - ALMÁSI, I. 2001. Interpretation of observed fluid potential patterns in a deep sedimentary basin under tectonic compression: Hungarian Great Plain, Pannonian Basin, Geofluids, vol. 1, 2001, no. 1, p. 11-36.

TULINIUS, H. - ÁDÁM, L. - STRACK, K. M. - YU, G. - HE, L. F. 2008. Geothermal Exploration Using Integrated 2-D MT and Gravity Surveys in Hungary; $70^{\text {th }}$ EAGE Conference \& Exhibition - Rome, Italy, 9 - 12 June 2008

HUNGARIAN GEOLOGICAL Survey. 2002. Assessment of the Domestic Geothermal Energy. Taken 1.12.2006 from http://www.mgsz.hu/english/mineral/mineral_4.html http://www.piacesprofit.hu/klimablog/energia

http://waterfire.fas.is

\section{Contact address::}

Adrienn Nagy, PhD student, Kitti Kollár, department engineer, László Péli, adjunct professor; Szent István University, Faculty of Economics and Social Sciences, Institute of Regional Economics and Rural Development, H-2100 Gödöllő, 1 Páter K, Hungary, e-mail: nagy.adrienn@gtk.szie.hu; e-mail: kollar. kitti@gtk.szie.hu; e-mail: peli.laszlo@gtk.szie.hu 